\title{
REFLECTIONS REGARDING SANCTIONS STIPULATED IN THE INTERNATIONAL TREATIES CONCERNING DISARMAMENT
}

\author{
D. Ş. Paraschiv
}

\author{
Daniel-Ştefan Paraschiv \\ Faculty of Law and Public Administration, Râmnicu Vâlcea, \\ "Spiru Haret" University, Râmnicu Vâlcea, Romania \\ *Correspondence: Daniel-Ştefan Paraschiv, Râmnicu Vâlcea, 30 General Magheru St., \\ Vâlcea, Romania \\ E-mail: drept_vl.paraschiv.daniel@ @ spiruharet.ro
}

\section{Abstract}

The main objective of the United Nations Organization, from its founding, is the exclusion of force from international relations, which also implies limiting the weaponry arsenal existent, until removing entire categories of it, as arms control and disarmament, even though they do not eliminate „per se” of political, economic or ideological reasons of using force, it significantly contributes to the diminishing of war risks.

When it is considered that the obligations resulting from disarmament treatment were infringed, one may appeal to the application of sanctions stipulated in the international law, the status of the author of infringement, as a reaction to the violation of the treaty.

Key words: disarmament, international sanctions, countermeasures, violation of treaties, state liability

\section{Introduction}

In cases when infringements of the disposition in the disarmament treaties are ascertained, the application of sanctions or other measures stipulated in the treaties breached is imposed, or in conformity with the general rules of international law, such as suspension of treaty, withdrawal from the treaty, countermeasures etc. Thus, states may adopt, individually or collectively, sanctioning measures against those who breach treaties in the disarmament domain, even in cases in which the respective agreements do not excessively stipulate this fact ${ }^{1}$.

\section{International Sanctions in Treaties Concerning Disarmament}

The concept of „disarmament: is used in a narrowed sense, that of numerical reduction or total elimination of a weapon system ${ }^{2}$, as well as in a large sense. In this latter one, by "disarmament", we understand all the measured targeted at: stopping, limiting, reducing or disbanding certain types of weapons; prohibiting certain military activities; regulating limitation in the placing of armed forces; prohibiting the transfer or certain articles of a military importance; reducing risks of accidentally starting war and limiting or reducing the use of certain types of weapons or methods of waging war. In other words, in a broad sense, the notion of "disarmament" also includes "weapon control"3.

\footnotetext{
${ }^{1}$ Sur S., Obligations en matière de désarmement et de limitation des armements: problèmes de respect et mesures d'imposition, L'Institut des Nations Unies pour la recherche sur le désarmement, Nations Unies, New York et Genève, 1995, p. 124.

2 "Disarmament" also has the notion of limiting armaments, imposed by a state, o group of states or an international organization at the end of war. Examples in this sense are the restrictions imposed on Germany, after the Second World War or on Irak, after the first war in the Golf (1991).

${ }^{3}$ Popescu D., Dezarmarea - concepte şi implicații juridice, in "Studii şi cercetări juridice”, no. 3, 1987, p. 35.
} 
Regularly, the disarmament agreements are achieved in the framework of the United Nations Organization or in another institutionalized specialized framework. At the level of the United Nations Organization, the General Assembly is the main organ with responsibilities in the disarmament field; aspects regarding disarmament are examined in the framework of the Disarmament Committee or even directly under the attention of the General Assembly, where member states have the opportunity to expose their official positions and to participate to informal consultations ${ }^{4}$.

The Security Council of the United Nations Organization has the obligation to elaborate plans for establishing a control and regulation system of weaponry ${ }^{5}$, having the ability to take measures in this sense ${ }^{6}$; similarly, the Council is actively involved in the process of imposing the observance of assumed liabilities by treaties by the party states.

In the year 1952 the Disarmament Commission was founded, as a successor of the United Nations Organization Committee for Atomic Energy and the United Nations Organization Committee for Conventional Armaments, which, including all the members of the United Nations Organization, has an activity status of inter-subsidiary body of the Igeneral Assembly, debating different concepts regarding disarmament.

On the European scale, the Organization for Security and Cooperation in Europe establishes one of the most efficient regional mechanisms of negotiation in the sphere of disarmament and security.

In this domain there were adopted numerous treaties with an universal, but also regional character, the majority forecasting guarantees and control mechanisms for respecting the obligations concerning disarmament, such as: national declarations ${ }^{7}$ or routine inspections ${ }^{8}$, etc.

Technological progress, especially in the domain of satellites, created the possibility of obtaining informations referring to respecting the disarmament treaties by means of ,noninvasive" technical procedures. Thus, listening systems can be assembled on satellites or planes which perform recognition actions, without the consent of the state targeted. Moreover, radars are used for surveillance, especially on cloudy weather and seismometers for detecting subterranean nuclear explosions, etc.

The reactions against states which infringe the obligations stipulated in the disarmament treaty are:

- Spontaneous and regulated (ad-hoc dispositions or submitted to conditions, such as notification, explanatory memorandum, moratorium);

- Unilateral or collective (adopted by a single international entity or by the majority of interested states, or even by the competent international organizations);

- Direct or indirect (direct taken by a party - parties - of the breached treaty, or which supposes seizing the Security Council of the united nations organization or

\footnotetext{
${ }^{4}$ Following the debates, the General Assembly adopts resolutions comprising proposals and recommendations. When they consider it necessary to give more attention to a certain aspect concerning disarmament, the General Assembly reunites in special sessions, the first in this sense being organized in the year 1978 .

${ }^{5}$ Art. 26 from the Charter of the United Nations Organization.

${ }^{6}$ For example, in the year 1991, the Security Council of the UNO adopted the Resolution no. 687 by with it was declared the elimination of chemical and biological weapons, as well as rockets carrying these types of weapons, owned by Irak.

${ }^{7}$ For example, in the Convention concerning the prohibition of development, production, stocking and use of chemical weapons, adopted in the 13th of January 1993 in Paris and entered in force on the 29th of April 1997, approved by Romania by the Law no. 125/9 December 1994 (Official Gazette no. 356/22.12.1994), shows that each state party undertakes to, in term of maximum 30 days from the entering in force of the Convention, to declare whether it possesses chemical weapons, their placement and quantity, to elaborate a destruction plan of these weapons, etc.

${ }^{8}$ Routine inspections target the verification of armament stocks, the process of reducing them and the way in which states conform to the obligation of stopping the production of weapons prohibited by treaties.
} 
other bodies, as to obtain support for ensuring the observance of treaties or fo the application of sanctions) ${ }^{9}$.

In some international treaties referring to disarmament in which there are no sanctions for the infringing parties, the possibility of seizing the Security Council is provided, situation in which it was established that a state party has breached the obligations assumed. For example, the Convention concerning the prohibition of development, production, stockage and use of chemical weapons and destroying them, acknowledges the right of the state parties that "in cases of particular gravity", to bring the issue, and including the relevant conclusions and informations, at the knowledge of the Security Council and General Assembly of the United Nations ${ }^{10}$. Similar to the situation of the Convention upon the prohibition of perfecting, production and stockage of bacteriological (biological) weapons with toxins and upon their destruction ${ }^{11}$, in art. VI, pct. 1 of the latter stipulating that: any state party of this Convention which ascertains that another state party breaches the obligations resulting from the dispositions of the Conventions may submit a complaint to the Security Council of the United Nations".

In the content of other treaties, such as the Treaty concerning the non-proliferation of nuclear $^{12}$, no reference is made regarding the notification of the Security Council for applying sanctions $^{13}$, in its content also being stipulated the guarantees and measures which may be taken for observing its dispositions.

The formal notification of the United Nations Organization or of other competent international organizations, in case of infringing the obligation undertook in the treaty, makes possible the bringing of the case to the public opinion, which constitutes, in itself, a sanction which affects the prestige and credibility of the state in case ${ }^{14}$.

The state which suffered damages by the violation of a treaty, may directly notify the Security Council ${ }^{15}$, in the absence of pertinent institutionalized mechanisms ${ }^{16}$, also

\footnotetext{
${ }_{9}^{9}$ Istrate C., Dreptul dezarmării. Acorduri multilaterale, All Beck Publishing, Bucharest, 2005, pp. 209-210.

${ }^{10}$ In conformity with art XIV, pct. 1 from the Convention" Disputes which may arise concerning the application or the interpretation of the present convention will be solutioned according to the pertinent dispositions of the present convention and in conformity with the dispositions of the United Nations Charter".

${ }^{11}$ The convention regarding the prohibition of perfecting, producing, stocking of bacteriological (biological) weapons with toxines, and upon their destruction was opened for signing on the 10th of April 1972, in London, Moscow and Washington and it entered in force on the 26th of March 1975; Romania approved this Convention by the Decree 253/6 July 1979 (Official Gazette no. 57/7 July 1979).

${ }^{12}$ Adopted on the 12nd of June 1968 by the General Assembly of the United Nations Organization, entered in force on the 5th of March 1976 and approved by Romania by the Decree of the State Council no. 21from the 31 st of January 1970, published in the Official Gazette no. 3/31 January1970.

${ }^{13}$ Security Councillor of the United Nations Organization must be notified in term of 3 months prior to the situation of a withdrawal from the Treaty of a state party (art. X, pct. 1, thesis 2).

${ }^{14}$ See also Larsen J.A., Rattray G.J., Arms Control Toward the $21^{\text {st }}$ Century, Lynne Rienner Publishers, Boulder (Colorado), 1996, p. 83, according to who the simple informing of the public concerning the breach of an agreement may even have contrary effects, in the sense of undermining the agreement, if sanctions will not follow.

${ }^{15}$ As it has been shown, the convention regarding the prohibition of biological weapons stipulates that any state who considers that any state party who breached the dispositions of the convention may file a claim to the Security Council of the United Nations Organization, attaching any proof to support the assertion, as well as requesting the examination by the Council. Similar dispositions are comprised in the Convention regarding the prohibition of techniques which modify the environment, in military or hostile purposes, adopted by the General Assembly of the United Nations Organization on the 10th of December 1976, and opened for signing on the 18th of May 1977 (Romania approved the Convention by the Decree no. 100/28.03 1983, published in the Official Gazette no. 23/01.04.1983).

${ }^{16}$ The Charter of the United Nations Organizations does not expressively entitle the Security Council to adopt measures against states which breach the obligations resulting from a disarmament treaty in which there are parties, but in the situation in which it considers that the situation created risks to determine international frictions, the Council may solicit the state or states affected, in conformity with the Chapter VI of the Charter, "adequate methods or procedures of settling conflicts".
} 
mentioning the proofs on which the notification is based ${ }^{17}$. The Council may decide that a certain breach of the obligations assumed by the treaty, constitutes ,a threat to peace", a hypothesis in which, according to the dispositions in the 7th Chapter of the Charter, it is entitled to request the member states of the United Nations Organization the application of sanctions to the state in case. These may be: the partial or total interruption of economic relations or rail, marine, aerial, postal, telegraphical, radio communications and other communication means, including force demonstrations, blockade and other operations of the armed forces belonging to the member states of the United Nations Organization ${ }^{18}$.

Formally, the Security Council has the necessary means to combat the perils of peace, resulting from the infringement of international agreements, but in practice, it is sometimes difficult to obtain the necessary consensus for taking measures, from its members, because although the majority requested of $2 / 3$ is met, the decision may be blocked by the veto ${ }^{19}$ of one of the five permanent members ${ }^{20}$; The veto right continues to function without restrictions, the nuclear powers refusing to limit their rights beyond the limits established by the United Nations Charter ${ }^{21}$.

In some cases, the Security Council has intervened in the innovative spirit with punitive measures ${ }^{22}$ which is only partially based on treaty dispositions ${ }^{23}$.

In the public international law there are other bodies or intergovernmental organizations, such as, the International Agency for Atomic Energy ${ }^{24}$ or the Organization for Prohibition of Chemical Weapons ${ }^{25}$, which may act on the application of sanctions for non compliance with the disarmament treaties. Thus, the infringement of disarmament treaties is reported to the Security Council and the General Assembly of the United Nations Organization. If these organizations fail to adopt recovery measures in a reasonable interval of time, the Governing Council of the International Agency of Atomic Energy may decide, as a

\footnotetext{
${ }^{17}$ Istrate C., [9], p. 214 and fol.

${ }^{18}$ Art. 41 and 42 from the United Nations Charter.

19 The issue of reconcilliating the right to veto with the imperative of applying treaties in the domain of disarmament appeared ever since the year 1946, in the context in which the USA proposed Baruch Plan, in view of creating an international agency to control nuclear energy. The United States insisted that the right of veto must not be used in the purpose of protecting those who infringe international treaties, however no result was obtained due to the opposition of other states. The abusive use of the right to veto was also analysed in other circumstances (for example, in the context of negotiations regarding the prohibition of biological weapons), showing that maintaining this right, in such situations, would contravene the equality sovereign principles and non-discrimination of states parties to the same treaty.

${ }^{20}$ Goldblat J., Arms Control - A Guide to Negotiations and Agreements, International Peace Research Institute, Oslo - Stockholm International Peace Research Institute, SAGE Publications, London - Thousand Oaks - New Delhi, 1994, p. 235 and fol.; Larsen J.A., Rattray G.J., [14], p. 83.

${ }^{21}$ See also Sims N.A., "The Evolution of Biological Disarmament", in Chemical and Biological Warfare Studies, No. 19, Stockholm International Peace Research Institute, Oxford University Press, New York, 2001, p. 53 and fol.

${ }^{22}$ See Sur S., [1], p. and fol.; Rice M., 1999, Security Council replaces UNSCOM; paves way for inspections, sanctions relief, in Arms Control Today, Arms Control Association, December 1999, p. 27 and fol.

${ }^{23}$ Thus, in the disarmament issue, by the Resolution no. 687 (1991) the Security Council established that Irak must destroy or render harmless all stocks of chemical and biological weapons, all research, development and production installations relevant in this field, as well as all ballistic missiles with range greater than $150 \mathrm{~km}$, their main components, as well as the production installations or rocket repairs. In conformity with the sanctioning regime applied to Irak, it should not have developed nuclear weapons, susceptible materials to producing these weapons, relevant research, development or production components or installations. Moreover, the exportation of weapons and military material to Irak was prohibited until the contrary decision of the Security Council.

24 According to art. III, pct. 1 from the Treaty concerning the nuclear non-proliferation, every state party undertakes to observe the guarantees stipulated in the agreement concluded with the International agency for Atomic Energy.

${ }^{25}$ Article VIII A from the Convention concerning the prohibition to develop, produce, stock and use chemical weapons and destroying them.
} 
sanction, the interruption or cancelling of assistance provided by the Agency and solicit the guilty state to return material or equipment which were already transferred. Moreover, one may decide the suspending of the state in case, from the benefit of rights and privileges offered by the quality member of the Agency ${ }^{26}$.

The conference of prohibiting chemical weapons provides a series of attributions of the Organization for Prohibition of Chemical Weapons in view of redressing the situation and ensuring the observance of assumed obligations, including the adoption of sanctions ${ }^{27}$. If the illicit activity of a state party may seriously damage the objective and target of the Convention, the conference of prohibiting chemical weapons may recommend the state parties to adopt collective measures, and in cases of extreme gravity, may also notify the General Assembly of the United Nations Organizations and the Security Council for taking the measures imposed ${ }^{28}$.

In establishing the legal regime of nuclear weapons the International Court of Justice was also involved, in the year 1996, when, at the initiative of multiple non-governmental organizations, the Global Heath Organization adopted a resolution by which it requested the International Court of Justice a consultative notice regarding the legality of using nuclear weapons, taking into account the consequences of using those weapons, for the health of the people and of the environment. In its notice, the Court showed that the use of nuclear weapons is ,contrary to the regulations of the international law applicable to armed conflicts and, especially to the principles and rights of the humanitarian law", but it also evidenced that „taking account of the current state of the international law and the elements at its disposal, the Court may not definitively decide if the threat or use of nuclear arms is legal or illegal in the extreme circumstance of self-defense, in which the survival of a state in itself may be questioned" 29 .

\section{Conclusions}

By studying international reality, it is observed that, although the nature of sanctioning measures against states that breach the obligations stipulated in the disarmament treaties is relevant, the primordial importance is represented by the proportionality of sanctions with the gravity of violating contractual obligations. In this way, a broad range of reactions/ countermeasures can be used for obtaining the desideratum of treaty compliance, which embodies economical measures (suspending the assistance programs, imposing commercial restrictions or ceasing the vital deliveries of raw materials, equipment), but also diplomatical and political measures, namely reducing the level and intensity of relations with the state in cause ${ }^{30}$. For example, taking into account the high level of peril, created by performing nuclear experiments by India and Pakistan in the year 1998, international reactions were extremely ferm, by being condemning of numerous states and international bodies ( United Nation Organization, International Agency for Atomic Energy, The Group of 8, Permanent Commune Council of the North Atlantic Organization Treaty - Russia) and warning upon the extensively baneful impact of these experiences for regional and global security. Likewise, certain countries withdrew the support offered to India for the occupation of a permanent member position in the Security Council of the United Nations Organizations. Moreover,

\footnotetext{
${ }^{26}$ Goldblat J., [20], p. 236 and fol.; Istrate C., [9], p. 210.

${ }^{27}$ Sur S., [1], p. 27 and fol. The conference of the member state of the Organization for Prohibition of Chemical Weapons is entitled to adopt recovery measures in view of observing the Convention, and in case of noncompliance of the measures adopted, it may reduce or suspend the rights and privileges of the state in cause, the sanctions remaining in force until taking the requested measures.

${ }^{28}$ Istrate C., [9], p. 211.

${ }^{29}$ See Sayed A., Quand le droit est face à son néant. Le droit à l'épreuve de l'emploi de l'arme nucléaire, Éditions Bruylant, Bruxelles, 1998, p. 66 and fol., which shows that the proof of rare sensibility of the issue analysed, the assertion regarding the notice reunited seven votes pro and against, the vote of the President of the International Justice Court, Mohamed Bedjaoui being necessary for the adoption of this notice.

${ }^{30}$ Istrate C., [9], p. 219.
} 
together with the political convictions, some states also adopted other unilateral sanctions, such as the ones imposed on India by the United states of America, which refers to the cancelling of economic assistance, except the one regarding food provision in humanitarian purposes; cancelling of armament sales and other military products; rejecting loan requests or of financial assistance; prohibiting the exportation of items or technologies subject to licenses $^{31}$.

\section{Bibliography} 2005;

Istrate C., Dreptul dezarmării. Acorduri multilaterale, All Beck Publishing, Bucharest,

Sims N.A., "The Evolution of Biological Disarmament", in Chemical and Biological Warfare Studies, No. 19, Stockholm International Peace Research Institute, Oxford University Press, New York, 2001;

Rice M., Security Council replaces UNSCOM; paves way for inspections, sanctions relief, in Arms Control Today, Arms Control Association, December 1999;

Sayed A., Quand le droit est face à son néant. Le droit à l'épreuve de l'emploi de l'arme nucléaire, Éditions Bruylant, Bruxelles, 1998;

Larsen J.A. \& Rattray G.J., Arms Control Toward the $21^{\text {st }}$ Century, Lynne Rienner Publishers, Boulder (Colorado), 1996;

Sur S., Obligations en matière de désarmement et de limitation des armements: problèmes de respect et mesures d'imposition, L'Institut des Nations Unies pour la recherche sur le désarmement, Nations Unies, New York et Genève, 1995;

Goldblat J., Arms Control - A Guide to Negotiations and Agreements, International Peace Research Institute, Oslo - Stockholm International Peace Research Institute, SAGE Publications, London - Thousand Oaks - New Delhi, 1994;

Popescu D., Dezarmarea - concepte şi implicații juridice, in "Studii şi cercetări juridice", no. 3, 1987.

\footnotetext{
31 These sanctions were cancelled on the 22nd of September 2001, in the context of the campaign against terrorism.
} 